\title{
Sensus communis. Esej o wolności dowcipu i humoru - część pierwsza
}

\section{Rozdział I}

Zastanawiałem się, przyjacielu, cóż to za myśl wzbudziła w tobie tak wielkie zdziwienie, kiedy pewnego razu wygłosiłem pochwałę kpiny (raillery) ${ }^{1}$. Czyżbyś miał mnie za kogoś zbyt poważnego na to, bym lubił tego rodzaju rozmowy? A może obawiałeś się, że nie sprostałbym próbie, gdybyś mnie na nią wystawił?

Muszę przyznać, że twoje wątpliwości były uzasadnione, jeśli przedstawiłeś mnie sobie jako gorliwca tak głęboko przekonanego o słuszności swych racji, że nie zniósłbym najmniejszej choćby kpiny. Wiem, że niektórzy ludzie

\footnotetext{
${ }^{1}$ Podstawą przekładu jest wydanie: Anthony Ashley Cooper, Earl of Shaftesbury, Characteristicks of Men, Manners, Opinions, Times, ed. Douglas den Uyl, Indianapolis 2001. Sensus communis to jeden z esejów wchodzących w skład pierwszego z trzech tomów Characteristicks, wydanych po raz pierwszy w 1711 roku. Pisarstwo Shaftesbury'ego (1671-1713), angielskiego moralisty i estetyka, wpisywało się w nurt angielskiego wolnomyślicielstwa i deizmu, reprezentowanego przez takich autorów, jak John Toland, Anthony Collins, Thomas Chubb czy Matthew Tindall. Po polsku ukazał się dotychczas tom: List o entuzjazmie. Moraliści, przeł. A. Grzeliński, Toruń 2007. Krótkie fragmenty pism filozofa w tłumaczeniu E. Stefańskiej opublikowano wcześniej w zbiorze Teoretycy, artyści i krytycy o sztuce 1700-1800, wybór, przedmowa i komentarz E. Grabska i M. Poprzędzka, Warszawa 1974.
} 
tacy właśnie są: ich zdaniem wszystko, co im samym wydaje się doniosłe albo poważne, należy traktować doniośle i poważnie. Co innego, jeśli rzecz dotyczy innych: wówczas chętnie postąpią odwrotnie, sprowadzając do śmieszności każdą, poza swą własną, opinię.

Pytanie jednak, czy jest to słuszne, czy nie, i czy nie byłoby właściwą i rozsądną rzeczą podchodzić z taką samą swobodą do własnych opinii, jak do cudzych? Czyniąc dla siebie w tej sprawie wyjątek, możemy wystawić się na podejrzenie o egoizm. Możliwe, że zostaniemy posądzeni o umyślną ignorancję i ślepe bałwochwalstwo, myląc opinie $\mathrm{z}$ wiarą i uświęcając w samych sobie pewne koncepcje niczym bóstwa, których rzeczywistego wyglądu nie chcielibyśmy, ani nigdy nie zdołalibyśmy zobaczyć. Możliwe, że są one nie bóstwami czy nienaruszalnymi prawdami, lecz potworami, które pragniemy trzymać w ciemnym zakamarku naszego umysłu. Kiedy na wszelkie sposoby wzbraniamy się przed ujrzeniem ich kształtów i barw w różnorakim świetle, widma te mogą objąć nad nami władzę. To, co ukazuje się zawsze tylko w jednym i tym samym świetle, można zawsze zakwestionować. Prawda, jak sądzę, może znieść każdy rodzaj światła, a jednym z najważniejszych, a przy tym jednym $\mathrm{z}$ naturalnych sposobów najpełniejszego poznania rzeczywistości, jest właśnie kpina; ten rodzaj rozumowania pozwala rozpoznać, co w danym przedmiocie rzeczywiście można wykpić. Tyle przynajmniej dopuszczają wszyscy, którzy kiedykolwiek odwołują się do tego sprawdzianu. Najpoważniejsi dżentelmeni, nawet jeśli piszą o najbardziej doniosłych tematach, powinni się z tym zgodzić i zaniechać odmawiania innym tej wolności, jeśli jednocześnie sami przyznają sobie swobodę krytykowania i nie mają skrupułów, aby ciągnąc najpoważniejsze nawet wywody, zapytać: „Czyż to nie jest śmieszne?"

Sądzę zatem, że powinieneś wiedzieć, jak zapatruję się na tę kwestię. Dzięki temu będziesz mógł osądzić, czy owego dnia byłem szczery, gdy broniłem kpiny, i czy nadal będę wstawiać się za tymi spośród naszych pomysłowych przyjaciół, których częstokroć potępia się za ów humor i swobodę, z jaką oddają się beztroskiemu sposobowi pisania i prowadzenia rozmowy.

\section{Rozdział II}

Jeśli poważnie zastanowimy się nad tym, jaki użytek czyni się czasem $\mathrm{z}$ tego rodzaju dowcipu, który w naszych czasach u niektórych ludzi rozwi- 
nięty jest ponad miarę, możemy popaść w zdumienie i stracić pewność, jakie mamy powziąć o nim zdanie i dokąd ów powszechny nastrój nas zaprowadzi. Najpierw panował on wśród tych, którzy gonili za przyjemnościami, potem przeszedł do ludzi interesu, wreszcie zaraził polityków, a najpoważniejsze sprawy państwa zaczęto traktować z domieszką ironii i przekory. Najzdolniejsi spośród prowadzących pertraktacje polityków dali się poznać jako najwięksi prześmiewcy, najznamienitsi zaś autorzy - jako najwięksi mistrzowie krotochwili.

Rzeczywiście istnieje pewien rodzaj usprawiedliwionej kpiny (o ile mogę ją tak nazwać), którą jestem gotów dopuścić zawsze wtedy, gdy mamy do czynienia ze zbytnią ciekawością, chcącą odkryć więcej prawdy niż da się bez kłopotu wypowiedzieć. W niektórych sytuacjach największą krzywdą, jaką można wyrządzić prawdzie, jest zbytnie wystawienie jej na światło dzienne. $\mathrm{Z}$ rozumem jest tak samo, jak ze wzrokiem: określonej wielkości i formie potrzebna jest określona ilość światła, a wszystko ponad to sprowadza ciemność i zamęt.

Ukrywanie brutalnych prawd przed wrażliwymi oczami jest oznaką prawdziwego człowieczeństwa i życzliwości, a posługiwać się przy tym przyjemną rozrywką jest o wiele łatwiej i uprzejmiej niż uciekać się do surowej odmowy albo wymuszonej powściągliwości. Kpinie nie przystoi jednak umyślne konfudowanie innych, wykorzystywanie swej przewagi i czerpanie przyjemności z zakłopotania, w jakie wprawia kogoś pełna niejasności rozmowa, gdy udajemy największą powagę albo uciekamy się do najbardziej uroczystego oszustwa. Współcześnie, tak jak i niegdyś, mądrzy ludzie muszą być może niekiedy posługiwać się parabolami i dwuznacznościami, gdy chcą rozweselić nieprzyjaciela, a jednocześnie sprawić, aby tylko ten, „kto ma uszy do słuchania, mógł słuchać”. Niewątpliwie jednak jest to pośledni, pozbawiony mocy i bezbarwny rodzaj dowcipu, który bawi wszystkich bez wyjątku i każdego, kto jest rozsądny, także przyjaciół, pozostawia w rozterce i niepewności co do czyjegoś zdania na jakiś temat.

Jest to ów niewybredny rodzaj kpiny, jakże obraźliwy w dobrym towarzystwie. I rzeczywiście, różnica pomiędzy jednym a drugim jest tak duża, jak między szczerością a hipokryzją, albo między najsubtelniejszym dowcipem a najbardziej grubiańskim błazeństwem. Jednak dzięki swobodzie rozmowy ten prymitywny rodzaj dowcipu traci rację bytu, dowcip jest bowiem swoim własnym lekarstwem. Wolność i swobodna wymiana między umysłami przywodzą go do właściwej mu miary, a jedynym niebezpieczeństwem jest nałożenie na nie embarga. Rzeczy mają się tu tak samo, jak w handlu. Nakazy 
i ograniczenia ograniczają dochód: nic nie jest dla nich równie korzystne jak wolny port.

Widzieliśmy w naszych czasach zmierzch i upadek fałszywego dowcipu, który tak bardzo zachwycał naszych przodków, że przepełnili nim zarówno swoje wiersze, sztuki, jak i kazania. Każdy rodzaj humoru miał w sobie coś z przewrotności. Nawet sąd posługiwał się grą słów. Ale teraz dowcip taki opuścił już miasta i wszelkie dobre towarzystwo. W całym kraju pozostały tylko nieliczne jego ślady i zdaje się, że na koniec ograniczył się do szkól, stając się główną rozrywką pedantów i ich uczniów. Tak więc pod innymi względami dowcip w naszych rękach ulegnie poprawie, a humor się udoskonali, o ile tylko zadbamy o to, by nie wchodzić im w drogę, nie ograniczać surowo ich użycia i nie pętać go rygorystycznymi przepisami. Wszelka uprzejmość wyrasta z wolności. Przyjaźnie ścierając się ze sobą, nadajemy sobie ogładę. Powstrzymywanie się przed tym oznaczałoby osłabienie ludzkiej zdolności porozumiewania się, zniszczenie uprzejmości, dobrego wychowania, a nawet samej dobrej woli - pod pozorem jej zachowania.

\section{Rozdział III}

Opis kpiny jest zadaniem tak trudnym, a nadto jałowym, jak zdefiniowanie dobrego wychowania, spekulacje na ten temat zrozumieją bowiem jedynie ci, którzy mają z nią do czynienia w praktyce. A jednak każdy myśli o sobie, że jest dobrze wychowany: najbardziej sztywny pedant wyobraża sobie, że potrafi kpić, nie tracąc przy tym wdzięku i humoru. Znam kilku poważnych dżentelmenów, którzy czuli się w obowiązku skarcić autora za obronę kpiny, gdy tymczasem, jakkolwiek oczywiście nieporadnie, sami nieustannie posługiwali się tą bronią. Jestem przekonany, że dotyczy to też wielu zelotów, którzy wzięli na siebie trud udzielenia odpowiedzi naszym wolnomyślicielskim pisarzom. Na przekór swym skłonnościom owi ponurzy dżentelmeni o zawziętym obliczu i postawie godnej prawdziwych inkwizytorów, z niechęcią porzucają swoją surowość, aby okazać przeciwnikowi dobry humor i uprzejmość. Aby oddać im sprawiedliwość, dodam, że nie wątpię wcale, iż to właśnie było ich zamiarem, niewiele to jednak może zmienić $\mathrm{w}$ ich postawie i zachowaniu. Według wszelkiego prawdopodobieństwa szybko porzuciliby oni farsę na rzecz czystej tragedii. Nie ma nic bardziej niedorzecznego niż janusowe oblicze współczesnych pisarzy, z jednej strony ukazujące wymuszony 
uśmiech, z drugiej zaś jedynie wściekłość i nieprzejednanie. Gdy tylko uda im się wejść do tego grona i gdy tylko przystaną na sprawiedliwe reguły walki na dowcip i humor, ledwie sięgną za swą broń, już słychać, jak głośno wołają o pomoc i sięgają po broń prawdziwie świecką.

Trudno o bardziej niedorzeczny widok niż oprawca i błazen odgrywający swoje role na tej samej scenie, a jednak jestem przekonany, że zna go każdy, kto zetknął się z kontrowersyjnymi pismami pewnych współczesnych gorliwców, którym daleko do mistrzostwa w posługiwaniu się zarówno powagą, jak i dobrym humorem. Tę pierwszą przemieniają zawsze w zgryźliwą surowość, drugi - w niezdarną błazenadę. I tak oto, zawieszeni między złością a uprzejmością, zachwytem a kpiną, mają w sobie tyle wdzięku, ile bawiące się kapryśne dzieci, którym niemal wystarcza jeden haust powietrza, aby jednocześnie płakać i śmiać się, gniewać się i figlować.

Nie muszę uciekać się do wyjaśnień, aby pokazać, z jaką przyjemnością czyta się ich pisma, jak zjednują oni ludzi i przekonują tych, którzy podobno są w błędzie. Dlatego też trudno mi się dziwić, gdy słyszę publiczne zawodzenia zelotów, lamentujących, że podczas gdy książki ich przeciwników są tak powszechnie czytane, to odpowiedzi na nie z trudem tylko można znaleźć, a nawet cokolwiek o nich usłyszeć. Pedanteria i fanatyzm są niczym kamienie młyńskie, zdolne pogrążyć najlepszą książkę, która miałaby dźwigać choćby odrobinę takiego śmiertelnego ciężaru. Obecnej epoce nie odpowiada usposobienie pedagoga, a choć można nauczać dzisiejszy świat, to pouczać go się nie da. Ludzie chętnie słuchają przemawiającego filozofa, o ile pozostaje wierny swojemu nauczaniu. Słuchaczy znajduje też chrześcijanin, o ile zgodnie ze swoją wiarą jest pełen miłosierdzia i pokory. Dżentelmenowi natomiast przystoi dowcip i kpina, jeśli tylko dobre wychowanie nie dopuszcza do nich wulgarności i błazenady. Kiedy jednak zwykły scholastyk okopuje się wraz z takimi cechami i pisze to o jednym, to o drugim, okazuje się wówczas równie niezdolny do zachowania właściwej postawy jako chrześcijanin, jak do użycia rozumu jako filozof, lub do posłużenia się kpiną jak osoba dobrze wychowana; czy zatem można się dziwić, że jego zapchany rupieciami mózg rodzi monstra, które wyśmiewa cały świat?

Jeśli myślisz, mój przyjacielu, że powyższym opisem uczyniłem krzywdę gorliwym pisarzom prowadzącym swą religijną krucjatę, przeczytaj choćby kilka stron któregokolwiek $\mathrm{z}$ nich (nawet jeśli akurat nie prowadzą sporu gdzieś daleko, ale w obrębie swej własnej grupy) i wtedy dopiero wydaj sąd na ten temat. 


\section{Rozdział IV}

Teraz, kiedy tyle już zostało powiedziane na temat autorów i ich pism, spełni się twoje życzenie i poznasz moje zdanie na temat rozmowy, szczególnie tej niedawnej, swobodnego rodzaju, podczas której, jak pamiętasz byłem obecny i kiedy, jak ci się wydawało, z wielką powagą powinienem był potępić uczestniczących w niej twoich przyjaciół.

Muszę przyznać, że była to rozmowa bardzo zabawna, a może nie tylko taka, skoro skończyła się tak nagle i w takim chaosie, że nie doprowadziła do żadnego z zagadnień poruszanych w dotychczasowych dysputach. Sądzę, że pewne szczegóły tej konwersacji nie powinny zostać zapisane i wystarczy, jeśli dam ci tylko ogólne o niej wyobrażenie. To prawda, że mnóstwo wyrafinowanych wywodów legło w gruzy i wiele poważnych rozumowań zostało obalonych, jednak wszystko to dokonało się bez obrazy którejkolwiek ze stron, a wręcz przeciwnie - przyczyniło się do udoskonalenia dobrego humoru towarzystwa, wzmagając apetyt na tego rodzaju rozmowy. Jestem przekonany, że gdyby to sam rozum miał wydać osąd w swojej własnej sprawie, musiałoby przyjść mu na myśl, że w istocie więcej zyskał, dyskutując w swobodny i poufały sposób, niż wtedy, gdy tak jak zwykle stanowczo trzymał się określonej opinii.

Ale może wciąż wątpisz w moją szczerość i zechcesz przekonywać mnie, że popadam w paradoks, chwaląc tę rozmowę jako korzystną dla rozumu, podczas gdy jej efektem była utrata wszelkiej pewności co do tego, nad czym, jak się zdawało, rozum niewzruszenie panował. Odpowiem, że według tego, jak pojmuję rozum, posługiwania się nim nie mogą nauczyć ani pisma uczonych, ani krasomówcze rozprawy. Wyłącznie nawyk rozumowania może stworzyć myśliciela, a nic nie jest większą ku temu zachętą niż płynąca z tego przyjemność (o ile ją tam znajduje). Wolność kpiny, prawo kwestionowania wszystkiego (przyzwoitym językiem) i dopuszczanie wyjaśniania albo odrzucania jakiegokolwiek argumentu bez obrazy dyskutanta, to jedyne warunki mogące sprawić, że tego rodzaju teoretyczne rozmowy są przyjemne. Prawdę mówiąc, dla ludzkości stały się one uciążliwe za sprawą rygoryzmu nałożonych na nie praw oraz przez rządy pedanterii i bigoterii, przekonanych, że panują w dyskusjach niczym dyktatorzy w swych własnych prowincjach.

Skarga „Czy zawsze muszę być tylko słuchaczem?” jest tak samo naturalna w przypadku teologii, moralności i filozofii, jak dawniej skarga prześmiewców w poezji. Niestałość jest bardzo przez ludzkość wyczekiwanym, potężnym prawem dysput. Rozum więcej zyskuje podczas trwającej minutę lub 
dwie konwersacji, składającej się z pytań i odpowiedzi, niż podczas ciągnącej się godzinami rozprawy. Przemowy nadają się tylko do tego, aby wzbudzać emocje: potęga deklamacji ma przerażać, wychwalać, olśniewać i zachwycać, nie zaś dawać satysfakcję czy pouczać. Swobodna narada podobna jest do bezpośredniej walki. W porównaniu $\mathrm{z}$ nią, inne rozmowy są jakby walką z nieistniejącym przeciwnikiem, mocowaniem się z samym tylko powietrzem. Dlatego przymus tkwienia na spotkaniu i wysłuchiwania przemówień na pewne tematy musi wzbudzać w nas niechęć i czynić równie przykrymi przemawiających, jak tematy poruszane w takich warunkach. Ludzie woleliby raczej dyskutować o błahostkach, zachowując swobodę i nie oglądając się na autorytety, niż poruszać najbardziej przydatne i najlepsze na świecie tematy, kiedy rządzi nimi powściągliwość i lęk.

Nie jest też tajemnicą, że ludzie są przeważnie tak mizernymi myślicielami i tak niewielkie mają zainteresowanie dla drobiazgowych dysput w towarzystwie na jakikolwiek trywialny temat, skoro nie chce im się wytężać rozumu przy okazji ważniejszych spraw i są zmuszeni sprzeczać się bez przekonania, podczas gdy potrzebują wówczas największej energii i siły. Sytuacja ta przypomina to, co dzieje się w silnych, zdrowych ciałach, gdy są pozbawione swoich naturalnych ćwiczeń i tkwią zamknięte w ciasnocie, gdzie muszą wykonywać osobliwe ruchy i skręty. Mają namiastkę działania i nadal się poruszają, jednak zupełnie brak im wdzięku. Tchnienia życiowe nie mogą tkwić martwo i bezczynnie w zdrowych i aktywnych członkach. Podobnie naturalna swoboda tchnień właściwa najrozumniejszym ludziom sprawia, że jeśli zostaną spętani i poddani kontroli, znajdą inny sposób, aby być w ruchu i znaleźć ulgę w skrępowaniu: czy to będzie burleska, błaznowanie czy bufonada, ludzie ci niewątpliwie będą zadowoleni, uwalniając się i biorąc odwet na swoich dręczycielach.

Jeśli ludziom zabrania się wypowiadać poważnie na pewne tematy, będą to czynić w sposób pełen ironii. Jeśli zabroni się im wypowiadać się w ogóle, albo jeśli będzie im za to grozić niebezpieczeństwo, wówczas udoskonalą swój kamuflaż, skryją się w mroku tajemniczości i będą mówić tak, by ciężko ich było zrozumieć i aby ci, którzy mają zamiar wyrządzić im szkodę, nie mogli pojąć, o co im chodzi. Tak oto kpina staje się coraz bardziej modna i zbliża się do skrajności, a nastrój prześladowań tym bardziej skłania do żartów: potrzeba swobody może wzbudzać potrzebę prawdziwej uprzejmości, ale i być powodem deprawacji bądź złego użytku z dowcipu i humoru.

Jeśli w tym względzie przekraczamy właściwą miarę tego, co nazywamy wytwornością manier i niekiedy jesteśmy skłonni zaczerpnąć rozweselają- 
cego wiejskiego powietrza, możemy być wdzięczni niedorzecznej powadze i cierpkiemu humorowi naszych wychowawców: a może to oni sami mogą sobie podziękować, zwłaszcza jeśli sami zostali potraktowani z największą surowością. Najciężej jest oczywiście tam, gdzie ograniczenia były najbardziej surowe. Im większy ciężar, tym bardziej cięta będzie satyra. Im większe zniewolenie, tym bardziej wyrafinowana błazenada.

Zdaje się to potwierdzać spojrzenie na kraje, w których duchowa tyrania jest największa. Otóż twórcami najlepszych błazenad są Włosi: w ich pismach, beztroskich rozmowach, w ich teatrach, na ich ulicach, najmodniejsze są błazenada i burleska. To jedyny sposób, w jaki biedni, zniewoleni nieszczęśnicy mogą uwolnić nieskrępowaną myśl. Musimy przyznać, że górują nad innymi w tego rodzaju dowcipie. Zastanawiające jest, czy my, którzy mamy więcej swobody, mniej sprawnie posługujemy się tym znakomitym rodzajem kpiny i dworowania?

\section{Rozdział V}

Zaiste, to z tego właśnie powodu skłonny jestem wierzyć, że starożytni odkryli tak niewiele z tego ducha, i że niemal niemożliwe jest znalezienie zwyczajnej krotochwili u jakiegokolwiek autora w epoce, gdy panowała większa ogłada. Istotnie, sposób, w jaki traktowali najbardziej nawet poważne tematy, daleki był od tego, który jest właściwy naszym czasom. Ich rozprawy na ogół były utrzymane w swobodnym i bezpośrednim stylu. Chcieli oni przedstawić prawdziwą dysputę i rozmowę poprzez nadawanie im formy dialogu i swobodnej debaty. Akcja rozgrywała się przeważnie przy stole, na publicznych drogach albo w miejscach spotkań, a zwyczajny dowcip i humor dysput rzeczywistych odzwierciedlał się w tych, które wymyślano. I to było właściwe, bez dowcipu i humoru bowiem rozum jest niemal zupełnie pozbawiony możliwości sprawdzenia się albo przekonania, że jest właśnie rozumem. Sędziowski głos i wyniosły ton pedagoga nakazuje cześć i podziw. Z utrzymywania innych rozumów na dystans i pozostawania poza ich zasięgiem można uczynić największy użytek. Jednak ten drugi sposób postępowania, przeciwnie, pozwala na najbardziej uczciwe zmagania i każe przeciwnikowi wykazać się całą swą siłą w bezpośredniej walce na udeptanym polu.

Nie ma potrzeby wyobrażać sobie, jaką korzyść zyskuje czytelnik, kiedy może mierzyć się z autorem, który jest gotowy stanąć $\mathrm{z}$ nim z równymi 
szansami, zrzucić koturny właściwe tragedii, przywdziać swobodniejszy strój i przyjąć bardziej naturalną postawę. Wyraz twarzy i ton głosu to potężna pomoc podczas odgrywania roli, a groźnie zmarszczona brew dopuści wiele mędrkowań, które nie ostałyby się przed łagodnym spojrzeniem. Pewien starożytny mędrzec zwykł mawiać, że „humor jest jedynym sprawdzianem powagi, a powaga humoru. Dlatego temat nieznoszący ironii jest podejrzany, a żart niepoddający się poważnemu zbadaniu, z całą pewnością jest świadectwem fałszywego dowcipu".

Jednak niektórych dżentelmenów tak przepełnia duch fanatyzmu i fałszywej gorliwości, że kiedy dowiadują się o kwestionowaniu zasad, sprawdzaniu nauk i sztuk oraz traktowaniu ważnych spraw z otwartością właściwą dobremu humorowi, wyobrażają sobie zaraz, że wszystkie wyznania muszą upaść, wszystkie zasady obrócić się w ruinę i świat zostanie całkowicie pozbawiony porządku i przyzwoitości. Obawiają się, albo udają obawę, że przez tę swobodę nawet religia znajdzie się w niebezpieczeństwie, toteż są tak pełni niepokoju i ostrożności wobec swobody w rozmowach prywatnych, jak gdyby nadużywano jej w publicznym gronie albo przed najbardziej poważnym zgromadzeniem. Jednak, na ile to rozumiem, rzecz wygląda zupełnie inaczej. Nie zapominaj, przyjacielu, że piszę do ciebie jedynie w obronie swobody w klubach i tego rodzaju wolności, jaki panuje wśród dżentelmenów i przyjaciół, którzy doskonale się znają. O tym zaś, że obrona swobody z tym właśnie zastrzeżeniem jest dla mnie czymś naturalnym, możesz wnioskować $\mathrm{z}$ tego, jak pojmuję samą swobodę.

Niewątpliwie narusza wolność publicznych zgromadzeń ten, kto obejmuje przewodnictwo bez wezwania i bez zaproszenia. Zadawać pytania albo przewodniczyć debatom obrażającym opinię publiczną, oznacza nie dorastać do poziomu innych. Takie tematy albo nie powinny być w ogóle publicznie poruszane, a przynajmniej nie tak, by dawać powód do skandalu czy niepokoju. $\mathrm{W}$ żadnym wypadku społeczeństwo nie może być przedmiotem drwiny, ani też nie można go ganić za jego kaprysy, gdyż zacznie ono myśleć, że się nim gardzi. W tym względzie to, co sprzeciwia się dobremu wychowaniu, sprzeciwia się także swobodzie. Udawanie wyższości wobec tego, co pospolite i gardzenie tym, co odpowiada większości, jest właściwe ludziom o niewolniczym charakterze.

Miłośnicy ludzkości szanują i poważają konwenanse oraz więzi ludzkie. Natomiast w towarzystwie najróżniejszych ludzi i w miejscach, gdzie spotykają się oni w całkowicie nieskrępowany sposób, czy to, aby zażywać rozrywek, czy też w innych sprawach, napaścią jest kazać im słuchać tego, na co nie 
mają ochoty i posługiwać się językiem, którego wielu z nich być może nigdy nie używało. Wzbijać się w tony niedostępne dla ogółu, zmuszać innych do milczenia i pozbawiać ich przywileju repliki narusza porządek publicznych debat. Natomiast w gronie znajomych, kiedy przyjaciele spotykają z zamiarem doskonalenia się w posługiwaniu się dowcipem i ze swobodą podchodzą do wszystkich tematów, nie widzę żadnego powodu, by ktokolwiek miał się poczuć obrażony przez kpinę i humor, które są przecież istotą tego rodzaju konwersacji, jedyną rzeczą, która wprawia towarzystwo w dobry nastrój i uwalnia je od formalności interesów oraz kurateli i dogmatyzmu szkół.

\section{Rozdział VI}

Wróćmy zatem do naszego wywodu. Jeśli najlepsze z naszych współczesnych konwersacji zwykły toczyć się przede wszystkim wokół drobiazgów, jeśli racjonalne rozprawy, zwłaszcza te najbardziej teoretyczne, straciły kredyt zaufania i popadły w niełaskę ze względu na swoją sztywność, to mamy wystarczający powód, by dopuścić więcej humoru i wesołości. Swobodniejsze podejście do tych tematów uczyni je przyjemniejszymi i bliższymi. Dyskusja o nich nie będzie się różniła od rozmów na inne tematy. Nie ma powodu, by psuły dobrą atmosferę albo pozbawiały uprzejmą rozmowę jej lekkości czy przyjemności. A przecież im częściej podejmuje się takie rozmowy, tym lepszy przynoszą efekt. Zaczniemy rozumować bardziej logicznie, rozumując z przyjemnością i bez skrępowania, wedle uznania podejmując albo porzucając takie tematy. Dlatego, podsumowując, muszę ci wyznać, że kpina, którą zauważyłeś, i efekt, jaki wywołała w naszym towarzystwie, wcale mnie nie gorszą. Nastrój był miły, a konfuzja, jaką zakończyła się nasza konwersacja przyjemna. Tę przyjemność odczuwam również teraz, kiedy uświadamiam sobie, że zamiast zniechęceni koniecznością wznawiania debaty, byliśmy tym bardziej gotowi spotkać się znowu i dyskutować o tych samych tematach, nawet $\mathrm{z}$ większą swobodą i satysfakcją niż poprzednio.

Jak wiesz, byliśmy długo zajęci rozważaniem zagadnień moralności i religii. Wśród różnych opinii powziętych i z wielką energią oraz pomysłowością utrzymywanych przez poszczególne strony, ten lub ów od czasu do czasu pozwalał sobie apelować do zdrowego rozsądku. Każdy dopuszczał taką apelację i był skłonny poddać się próbie, nigdy nie mając pewności, że zdrowy rozsądek go usprawiedliwi. Jednak kiedy dany temat został już podjęty, a sprawa 
stanęła przed tym trybunałem, nie można było ogłosić żadnego wyroku. Mimo to strony z równą chęcią były gotowe, aby przy najbliższej nadarzającej się okazji ponownie apelować do zdrowego rozsądku. Nikt nie odważył się kwestionować autorytetu tego trybunału, dopóki pewien dżentelmen, którego osąd nigdy dotąd nie został podany w wątpliwość, nie zapragnął, aby ktoś $\mathrm{z}$ jego towarzyszy powiedział mu, czym jest zdrowy, powszechny rozsądek (common sense).

„Jeśli przez słowo 'rozsądek' (sense) mielibyśmy rozumieć opinię albo osąd, a przez słowo 'powszechny' (common) ogół albo jakąkolwiek znaczną część ludzkości, powiedział, byłoby trudno odkryć, kto posiada ów zdrowy rozsądek. To bowiem, co jest rozsądne według jednej części ludzkości, jest wbrew rozsądkowi według drugiej. Gdyby zaś o tym, czym jest zdrowy rozsądek, miało decydować zdanie większości, zmieniałby się on tak często, jak zmieniają się ludzie - to, co było w zgodzie ze zdrowym rozsądkiem dziś, byłoby wbrew niemu jutro albo niedługo potem".

Mimo różnic w przekonaniach ludzi na większość tematów, powinno być przecież kilka takich, co do których wszyscy powinni się zgodzić i myśleć to samo. Pytaniem pozostaje, cóż to jest. „Wydaje się, że wszystko, czego może on dotyczyć, można zawsze sprowadzić do religii, polityki albo moralności”.

Nie było sposobności mówić o sporach religijnych. Sprawa była wszystkim świetnie znana, gruntownie przemyślana przede wszystkim $\mathrm{w}$ gronie chrześcijan. Jedni po drugich podjęli poważną próbę: żadna ze stron, która kiedykolwiek miała władzę, nie zaniechała starań, żeby swój prywatny rozsądek uczynić powszechnym. Jednak wszystko na próżno. Zdrowy, powszechny rozsądek był nadal tak trudny to określenia, jak katolicki czy prawosławny. To, co dla jednego było niepojętą tajemnicą, drugi pojmował z łatwością. To, co dla jednego było absurdem, dla drugiego było czymś, co można udowodnić.

Również w polityce aktualne pozostaje pytanie o to, jaki albo czyj rozsądek mógłby zyskać miano powszechnego. Jeśli racja leży po stronie rozsądku Brytyjczyków albo Duńczyków, niewątpliwie mylą się Turcy i Francuzi. A wydaje się, że czysty nonsens, jakim jest bezwolne posłuszeństwo, zajął miejsce zdrowego rozsądku w większości nas, w Europie i wśród mieszkańców innych części świata.

Jeśli chodzi o moralność, różnice, o ile to w ogóle możliwe, są jeszcze większe. Nie biorąc pod uwagę opinii i zwyczajów licznych barbarzyńskich i niepiśmiennych narodów, widzieliśmy, że nawet te, które doszły do pisma i do filozofii, jak dotąd nie mogły się zgodzić na jeden i ten sam system albo 
honorowanie tych samych zasad moralnych. Niektórzy z naszych najbardziej podziwianych współczesnych filozofów uczciwie przyznali nawet, że cnota i wada nie mają ostatecznie innych praw i miary jak tylko moda i zwyczaje.

Możliwe, że naszym przyjaciołom wydało się to niesprawiedliwe, skoro tylko poważniejsze tematy traktowali $\mathrm{w}$ ten sposób, wyrzekając się przyjemniejszych. W weselszej części życia nasze kaprysy są tak samo istotne, jak w najbardziej poważnej. Problem w tym, że tylko połowicznie znosimy śmiech. Fałszywa szczerość jest wyśmiewana, ale nieszczere żarty mają się całkiem dobrze i stają się tak samo przewrotne. Nasze rozrywki, nasze sztuki, nasze uciechy stają się poważne i uroczyste. Marzymy o szczęściu, posiadaniu i przyjemnościach, których nie rozumiemy i których jesteśmy niepewni, a mimo to dążymy do nich tak, jak gdyby były najbardziej znanymi i najbardziej pewnymi rzeczami na świecie. Nie ma nic bardziej niemądrego i zwodniczego niż częściowy sceptycyzm. Skoro bowiem po jednej stronie utrzymuje się wątpliwość, po drugiej tym bardziej umacnia się pewność. Kiedy ekstrawagancja tylko z jednej strony jawi się jako śmiesznie absurdalna, $\mathrm{z}$ drugiej staje się tym bardziej uroczysta i podstępna.

Nie dotyczy to jednak naszych przyjaciół, którzy wydają się lepszymi krytykami, bardziej pomysłowymi i bezstronnymi w podawaniu w wątpliwość zastanych opinii oraz ujawnianiu absurdów. A jeśli pozwolisz mi pisać w tym samym nastroju, odważę się doprowadzić ów sprawdzian do końca, dociekając, jaka niezawodna wiedza albo pewność rzeczy może zostać ocalona i to w sposób, o którym sądziłeś, że prowadzi do utraty wszelkiej pewności i do wszechogarniającego sceptycyzmu. 